i prawdopodobnie otrzymamy przynajmniej po jednym, a może jeszcze dwa lub trzy tomy, dotyczące zbiorów tych wielkich kolekcji rękopisów.

Cechą charakterystyczną VII tomu jest długie wprowadzenie, będące zarazem wprowadzeniem do serii tomów, które będą opisywały kodeksy chryzostomiańskie w Bibliotece Narodowej w Paryżu. Wprowadza ono w wielkie zasoby rękopisów greckich znajdujących się w Bibliothèque Nationale w Paryżu, a także pozwala czytelnikowi zapoznać się z historią tego zbioru, sięgającą XVI wieku (z punktu widzenia, oczywiście, omawianych rękopisów Jana Chryzostoma).

Znaczenie tego zbioru chryzostomiańskich rękopisów greckich w paryskiej Bibliotece Narodowej polega również między innymi na tym, że to właśnie one służyły jako podstawa wydania dzieł Jana Chryzostoma w Paryżu, w latach 17181738 przez Bernarda de Montfaucon (1655-1741), benedyktyna z Kongregacji św. Maura (Maurynów), a przed nim przez innego wydawcę niektórych dzieł Chryzostoma, dominikanina, François Combefis (1624-1679). Wydanie Montfaucon'a, przedrukowane następnie przez Migne'a w jego Patrologia Graeca (tomy 47-64), stanowi do dziś podstawowy i najczęściej używany tekst dzieł biskupa konstantynopolitańskiego. To właśnie wydanie omawia Autor we wstępie, a następnie przedstawia jego przepracowanie w latach 1834-1839, którego dokonali Alexis i Józef Gaume przy pomocy innych specjalistów. Montfaucon korzystał w swym wydaniu nie tylko z rękopisów francuskich, ale także uciekał się do pomocy uczonych z całej Europy, którzy kolacjonowali dla niego rękopisy, choć wydawca nie zawsze z nich korzystał. Warsztat Monfaucon'a pokazuje niewydana dotąd praca M.L. Concasty, na którą powołuje się Autor.

Rękopisy tu opisane dotyczą przeważnie homilii egzegetycznych Chryzostoma, a więc Homilii do Księgi Rodzaju, Homilii do Ewangelii św. Mateusza, Homilii do Ewangelii św. Jana, Homilii do Dziejów Apostolskich i Homilii do Psalmów. Najwięcej, bo aż pięćdziesiąt trzy, rękopisów mają Homilie do Księgi Rodzaju, podczas gdy Homilie do Psalmów i Homilie do Dziejów Apostolskich mają po sześć rękopisów.

Nowy tom Codices Chrysostomici Graeci powiększa znacznie naszą znajomość tradycji kodykologicznej dzieł Jana Chryzostoma i pozwala nam też poznać proces wydawania jego pism.

Ks. Marek Starowieyski - Warszawa, UW

\title{
Józef POCHWAT MS, „Misterium iniquitatis”. Studium tajemnicy niepra- wości w dzielach Jana Kasjana (360-435), Kraków 2012, Wydawnictwo La Salette, ss. 383.
}

Badania naukowe dotyczące Ojców Kościoła i pisarzy kościelnych są nie tylko cenne ze względów historycznych (poznanie faktów, sposobu myślenia, okoliczności), ale posiadają swoją wartość teologiczną i egzystencjalną. Autorzy wczesnochrześcijańscy bowiem (nawet ci, którzy nie zawsze zaliczani są 
do ortodoksyjnych) dzielą się swoim doświadczeniem spisując myśl, która jest owocem zarówno pracy intelektualnej, jak też osobistym przeżywaniem relacji z Bogiem. Dzięki misteryjnej obecności Ducha Świętego głos świadków Chrystusa nigdy nie traci swojej aktualności, a wręcz przeciwnie - sprawia, że Kościół mimo różnych przeciwności może jeszcze bardziej zdecydowanie głosić prawdę o zmartwychwstaniu. Dlatego nie wolno lekceważyć źródła teologicznego, jakim są pisma Ojców Kościoła i pisarzy kościelnych. Ten fakt doskonale ukazuje wydana w 2012 r. nakładem Wydawnictwa Księży Misjonarzy Saletynów „La Salette” książka autorstwa ks. Józefa Pochwata: „,Misterium iniquitatis". Studium tajemnicy nieprawości w dzietach Jana Kasjana (360-435), która jest pozycją godną uwagi nie tylko dla teologa, ale i każdego, kto chce pogłębić swoją wiedzę religijną i życie duchowe.

Struktura monografii jest przedstawiona logicznie i przejrzyście. Całość została podzielona na dwie zasadnicze części poprzedzone Wstępem (ss. 13-19), a zwieńczone Zakończeniem (ss. 329-335) oraz bogatą Bibliografia (ss. 347-375) i Indeksem rzeczowym (ss. 381-383), który niewątpliwie ułatwia czytelnikowi korzystanie z opracowania. Każdy rozdział zawiera też krótkie wprowadzenie i podsumowanie, co od strony formalnej ułatwia zrozumienie argumentacji Autora.

We Wstępie ks. Pochwat kreśląc status quaestionis omawianego przez siebie tematu, przytacza zasadnicze opracowania z zakresu demonologii: G. Summy (Gestliche Unterscheidung bei Johannes Cassian, Studien zur systematischen und spirituellen Theologie 7, Würzburg 1992) i V. Codiny (El aspecto cristológico en la espiritualidad de Juan Cassiano, OCA 175, Roma 1966), wskazuje też na obszerne hasła encyklopedyczne: C. Colpe (Jenseitsfahrt II (Unterwelts- oder Höllenfahrt), RACh XVII 466-489) oraz P.G. van der Nata (Geister, RACh IX 716757). $\mathrm{Z}$ zakresu literatury polskiej wymienia takich autorów jak: T. Kaczmarek (Zto o charakterze osobowym - Szatan $w$ refleksji teologicznej $i$ doświadczeniu Kościoła, SWł 6: (2003) 241-254), L. Wrzoł (Wiadomości wstępne. Jan Kasjan: jego życie, dzieła i znaczenie, w: Jan Kasjan, Rozmów dwadzieścia cztery, POK 6, Poznań 1928, I-XVII), czy A. Nocoń (Wstęp, w: Jan Kasjan, Rozmowy z Ojcami, ŹM 28, Kraków 2002, 19-59). Jako szczególnie ważne dla swoich badań uznaje prace T. Trębacza (Szatan jako źródło zła. Studium dogmatyczno-pastoralne, Kraków 2010) oraz R. Wiśniewskiego (Szatan i jego studzy. Rola diabłów i demonów w tacińskiej literaturze hagiograficznej IV $i V w$., Chrześcijaństwo u schyłku starożytności. Studia Źródłoznawcze 4, Kraków 2003). Wszystkie te opracowania poruszają zagadnienie demonologii, nie podejmują jednak głębszej refleksji na temat teologii Jana Kasjana, który często nawiązywał do tematyki genezy zła, jego obecności w życiu człowieku, przejawów tego zła w świecie stworzonym, a także do form kuszenia szatańskiego.

Swoje badania ks. Pochwat oparł na analizie zachowanych tekstów Jana Kasjana. Chociaż nie podjął krytyki tekstów, przyjmując ustalenia wcześniejszych badaczy, wskazał jednak na pewne niekonsekwencje teologiczne, dotyczące nauki Jana Kasjana np. na temat natury złych duchów. Na s. 106 czytamy: „Jak łatwo zauważyć 
Jan Kasjan nie jest jednoznaczny w swoim przekazie dotyczącym duchów nieczystych. Raz mówi, że są duchami, innym razem, że są subtelne jak powietrze. [...] prawdopodobnie [...] nie wiedział, jak jednoznacznie ująć to zagadnienie"; i dalej (s. 107): ,ten błąd powtarzali np. egipscy pustelnicy, idąc za Orygenesem i niektórymi greckimi filozofami (stoikami i neoplatończykami). Kasjan błędnie odczytał nauczanie św. Pawła Apostoła sądząc, że dla niego aniołowie to ciała niebieskie, a materią - ciała ziemskie".

W pierwszej części książki (ss. 22-81) ks. Pochwat kreśli historyczny kontekst działalności mnicha z Marsylii oraz prezentuje jego biografię. Referując najważniejsze wydarzenia dla całego Kościoła i Imperium Rzymskiego przedstawia je w kontekście ich wpływu na dzieje i rozwój monastycyzmu. Analiza historyczna ukazuje także sytuację społeczną oraz proces rozwijania się w Kościele takich herezji jak arianizm czy pelagianizm, które warunkowały kierunek myślenia i polemiki Jana Kasjana. Dzięki nakreśleniu tła historycznego czytelnik może dokładniej zrozumieć, dlaczego teologia tego mnicha przybrała taki, a nie inny kształt.

Druga część (ss. 83-327) poświęcona jest wykładowi teologii Jana Kasjana i podzielona na trzy rozdziały. W pierwszym (ss. 83-141) ks. Pochwat skupia swoją uwagę na tekstach naszego mnicha, dotyczących takich zagadnień jak: kim jest szatan, określenie jego imion, opis dramatu upadku aniołów, natura złych duchów. Szczególnie ciekawym tematem jest przedstawienie nauki Kasjana na temat hierarchiczności w świecie demonów. Zróżnicowanie złych duchów wynika z ich złośliwości i przydatności w kuszeniu do grzechu, do którego najmocniej skłaniają człowieka. Opierając się na Starym i Nowym Testamencie oraz autorytecie innych pustelników, Kasjan ukazał ich struktury na wzór armii, w której występują zwykli żołnierze i dowódcy. Warto zaznaczyć, że według mnicha z Marsylii owe duchy nie tylko kierują swoją działalność przeciw człowiekowi, ale także rywalizują między sobą. To niewątpliwie szczególny wycinek jego teologii.

W rozdziale II (ss. 142-230) drugiej części książki została omówiona refleksja Jana Kasjana na temat oddziaływania złych duchów na człowieka. Szczegółowo została tu przedstawiona kwestia opętania człowieka przez szatana, z rozróżnieniem na opętanie ciała i duszy. W tym miejscu należy zwrócić uwagę na fakt, że Kasjan przestrzegał przed grzechem pychy tych, którzy posiadali dar wyrzucania złych duchów. Chociaż ów dar może być owocem osobistej świętości, to jednak zawsze swoją skuteczność czerpie z mocy Boga. Ponadto mnich podkreśla, że ważniejsza od wypędzenia szatana jest osobista walka wewnętrzna. Prawdziwe zmaganie się z nieprawością dotyczy walki z pokusami, grzechem, wadami i ich skutecznym opanowaniem. W tym kontekście należy wspomnieć, że Kasjan starał się cały czas zachować równowagę pomiędzy łaską a czynem ludzkim. Były to czasy, gdy spór ołaskęmiędzy św. Augustynema Pelagiuszemnie byłjeszcze wtedy ostatecznie rozstrzygnięty. Dlatego też ks. Pochwat powołując się na opracowania O. Chadwicka (Cassianus, TRE VII 650-657) i C. Stewarta (Kasjan Mnich, Kraków 2004) na s. 175 stwierdza: „Kasjan nie był konsekwentny w przedstawianiu teologii łaski 
Bożej i wolnej woli człowieka. Nie poszedł za chrystologicznymi ujęciami Augustyna z Hippony, ale - częściowo - za sugestiami Pelagiusza”.

Rozdział III (ss. 231-328) drugiej części systematyzuje nauczanie Jana Kasjana dotyczące wybawienia człowieka spod wpływu złych duchów, wad i grzechu. Wolność od działania zła może przynieść tylko Bóg, który przez realne wcielenie Syna dokonuje dzieła odkupienia. Dzięki temu dla każdej osoby, która wierzy, że Jezus jest Bogiem i człowiekiem, otwiera się perspektywa zbawienia i pokonania nieprawości. W tym kontekście Kasjan mocno krytykuje nestorianizm, który w jego opinii jest szatańskim wymysłem, i należy wprost do misterium nieprawości. $Z$ badań wynika, że mnich marsylski miał błędne przekonanie co do tego nurtu w teologii, dlatego ks. Pochwat krytycznie stwierdza: „tej opinii Kasjana w świetle pism Nestoriusza oraz dzisiejszych badań patrologicznych nie da się utrzymać".

Reasumując trzeba stwierdzić, że ks. Józef Pochwat starał się ukazać całe bogactwo myśli Jana Kasjana w określonym tematem zagadnieniu, a zarazem aktualność jego nauczania dla współczesnych. Cenne jest także wyodrębnienie błędów semipelagianizmu, pojawiających się w nauce mnicha z Marsylii. Autor monografii zachęca, by spojrzeć na tę postać z punktu widzenia historycznego, a nie tylko z perspektywy dogmatycznej polemiki, bo wtedy właśnie można nad dysputami teologicznymi dostrzec człowieka, który całym sercem chce naśladować Chrystusa i w ten sposób osiągnąć doskonałość chrześcijańską.

Książka ks. Józefa Pochwata MS jest rzetelnym i krytycznym opracowaniem myśli Jana Kasjana. Zasługuje na uwagę odbiorcy nie tylko ze względów poznawczych, ale także z perspektywy osobistego rozwoju duchowego. Opracowanie to jest źródłem wiedzy o strategii i działaniu szatana, i może być pomocą dla uniknięcia duchowych zagrożeń. Książkę tę warto polecić przede wszystkim tym, którzy chcą prowadzić badania teologiczne i poznawać szczegółowo historię monastycyzmu, sposób myślenia i duchowość pustelniczą. Dodatkową zaletą pozycji jest także to, że może po nią sięgnąc czytelnik bez pełnego przygotowania teologicznego, z powodzeniem będzie mógł zrozumieć bowiem wiele ważnych kwestii dotyczących duchowości i wzrastania w łasce.

Obecnie na rynku wydawniczym pojawia się bardzo wiele publikacji z zakresu demonologii, a szczególnie dotyczących opętania i zniewolenia duchowego. Często jednak dokonuje się przeakcentowania w stronę sensacji. W tym kontekście książka ks. Józefa Pochwata jest ich zupełnym przeciwieństwem, bo poruszając zagadnienie obecności osobowego zła wokół człowieka i walki duchowej, kładzie akcent na dzieło zbawcze Chrystusa oraz osobisty rozwój człowieka poprzez współpracę z łaską Bożą. Tym bardziej więc jest godna polecenia każdemu czytelnikowi. 